\title{
PROGRAM EVALUATION OF COACHING CLASS PERFORMANCE SPECIFIC SPORTS IN SMA N 1 SUKABUMI
}

\begin{tabular}{ll} 
& Yusep Permana \\
& ${ }^{1}$ SMA Negeri 1 Sukabumi \\
& ${ }^{1}$ yuseppermana1964@ gmail.com \\
\hline \multicolumn{1}{c}{ Info Artikel } & Abstrak \\
\hline Sejarah Artikel: & Tujuan dari penelitian ini untuk mengetahui program \\
Disetujui November & pembinaan prestasi kelas khusus olahraga yang \\
Dipublikasikan Desember & dilakukan oleh SMA Negeri 1 Kota Sukabumi dengan \\
& menggunakan model evaluasi CIPP (Context, Input, \\
& Process dan Product). Dengan menggunakan metode \\
& CIPP yang dikemukan oleh Daniel L. Stuflebeam yaitu \\
& evaluasi pada Context pembahasan mengenai latar \\
& belakang program dan tujuan program pembinaan. \\
& Evaluasi Input pembahasan mengenai penerimaan atlet, \\
& pelatih, dana, sarana dan prasarana. Evaluasi Process \\
& pembahasan mengenai pelaksanaan program latihan, \\
& konsumsi/gizi, koordinasi dan komunikasi. Evaluasi \\
& Product yaitu mengenai hasil capaian prestasi yang di \\
& dapat pada pembinaan prestasi kelas khusus olahraga \\
& SMA Negeri 1 Kota Sukabumi. Hasil penelitian ini \\
& diperoleh dari hasil wawancara, pengamatan (observasi) \\
& dan studi dokumentasi yang didapat peneliti bahwa \\
program pembinaan prestasi olahraga kelas khusus \\
olahraga SMA Negeri 1 Kota Sukabumi Pentingnya \\
komunikasi dan koordinasi dari stakeholder olahraga \\
belum berjalan sesuai harapan dalam mencari donatur \\
baik pihak pemerintah daerah dan swasta. Kesimpulan \\
bahwa:(1) Program pembinaan prestasi olahraga kelas \\
khusus olahraga dapat dijadikan model pembinaan \\
prestasi di sekolah umum,.
\end{tabular}

Kata Kunci :

Evaluasi, Program Pembinaan,

Prestasi Olahraga

Keyword : Evaluation, Program

Development, Sports

Performance

The purpose of this study was to determine the performance development program for a special sports class conducted by SMA Negeri 1 Sukabumi using the CIPP (Context, Input, Process and Product) evaluation model. By using the CIPP method proposed by Daniel L. Stuflebeam, namely evaluation of the context of the discussion regarding the program background and the objectives of the coaching program. Evaluation Input discussion regarding acceptance of athletes, coaches, funds, facilities and infrastructure. Evaluation Process of discussion regarding the implementation of training programs, consumption / nutrition, coordination and communication. Product evaluation is about the results of the achievements obtained in coaching the special class achievements of sports at SMA Negeri 1 Sukabumi City. The results of this study were obtained from the 
results of interviews, observations and documentation studies obtained by researchers that the sports achievement coaching program for sports special class SMA Negeri 1 Sukabumi City The importance of communication and coordination from sports stakeholders has not gone as expected in finding donors, both local government private. The conclusion is that: (1) A special sports class sports achievement development program can be used as a model for achievement development in public schools.

(C) 2020 Universitas Suryakancana e-ISSN : 2721-7175(online) p-ISSN : 2089-2341 (cetak)

\section{PENDAHULUAN}

Olahraga prestasi tidak dapat berkembang secara berdiri sendiri sehingga membutuhkan sinergi semua pihak, guna menjamin pembangunan olahraga yang berkelanjutan. Lemahnya pembinaan prestasi olahraga yang berkelanjutan sangat bertentangan dengan tuntutan olahraga prestasi yang hanya akan berhasil menakala prinsip pembinaan prestasi olahraga jangka panjang yang konsisten, berkesinambungan dan berkelanjutan. Sebagaimana sering didalihkan oleh para ahli yaitu pembinaan olahraga prestasi harus dimulai sejak usia dini hingga mencapai prestasi puncak, yang berlangsung melalui proses pembinaan berkelanjutan selama 10-12 tahun, atau sekurangnya 10.000 jam latihan, oleh karena itu pelaksanaan pembinaan olahraga prestasi sangat menekankan proses, ketimbang produk (hasil) (Rusli Lutan, 2013: 3).

Dewasa ini olahraga menjadi parameter kemajuan dan kekuatan suatu negara. Setiap negara memperlihatkan kekuatanya dengan menampilkan prestasi terbaik di ajang olahraga multi event internasional seperti SEA Games, Asian Games, dan pucak prestasi olahraga dunia adalah Olimpik Games. Multi event tersebut merupakan tolok ukur kemajuan suatu bangsa untuk melihat seberapa besar sumber daya manusia yang disiapkan dalam kegiatan olahraga untuk meraih prestasi setinggi-tingginya China/Tiongkok mampu menyelenggarakan multi event Olimpik Games dan Asian Games dengan predikat sukses pelaksanaan dan sukses prestasi sebagai Juara Umum pada tahun 2010 di Asian Games dan tahun 2001 pada Olympic Games. Sampai saat ini tahun 2014 pelaksanaan Asian Games di Incheon, Korea Selatan, China/Tiongkok mampu mempertahankan puncak prestasi sebagai Juara Umum.

Sekolah Menengah Atas

(SMA) merupakan jenjang pendidikan formal dibawah Kementerian Pendidikan dan Kebudayaan yang sekarang adalah yang bertanggungjawab terhadap penyelenggaraan pendidikan di Indonesia. 
Dimana pemerintah menyusun kurikulum seluruh mata pelajaran termasuk mata pelajaran olahraga yaitu Pendidikan Jasmani, Kesehatan dan Olahraga (PJOK) yang merupakan mata pelajaran pokok yang dialokasikan waktunya 2 jam pelajaran dalam satu minggu. Sehingga dirasakan kurang waktu yang dibutuhkan siswa dalam mengikuti pelajaran Penjaskesor. Namun bagi siswa yang sudah menjadi atlet sangat disayangkan kalau pembinaan prestasinya sampai terhenti akibat tidak diakomodirnya kelas khusus olahraga bagi para atlet junior yang ingin terus berprestasi.

SMA Negeri 1 Kota Sukabumi berada dibawah naungan Kementerian Pendidikan dan Kebudayaan (Kemendikbud) melalui Dinas Pendidikan Provinsi Jawa Barat. Kurikulum mata pelajaran yang diberlakukan pun hampir sama dengan sekolah umum negeri atau swasta tingkat menengah atas (SMA) lainnya. Sehingga tidak ada perlakuan khusus bagi siswa yang menjadi atlet di SMA Negeri 1 Kota Sukabumi tidak mengikuti seluruh mata pelajaran pada umumnya. Mereka dituntut belajar secara maksimal dengan mengikuti kegiatan belajar pada hari dan jam yang sama dengan siswa lainnya yang tidak masuk kelas khusus, dan tetap mengikuti program periodisasi latihan yang sudah dipersiapkan masing-msing cabang olahraga yang dipilih.

Namun demikian siswa yang berada di kelas khusus olahraga masih tetap berprestasi dalam mengikuti kejuaraan atau kompetisi baik single event dan multi event di tingkat nasional dan internasional sekalipun. Faktanya hampir setiap kompetisi/kejuaraan yang mereka ikuti selalu meraih prestasi baik pringkat 1 maupun sebagai runner up. Beranjak dari penjelasan dan data empirik yang didapat di lapangan, peneliti tertarik untuk mengangkat penelitian terhadap pelaksanaan program pembinaan prestasi kelas khusus olahraga di SMA Negeri 1 Kota Sukabumi.

Berdasarkan catatan prestasi yang di dapat dari kelas khusus olahraga SMA Negeri 1 Kota Sukabumi menarik peneliti untuk melakukan suatu penelitian melalui kajian ilmiah secara empirik. Bagaimana model program pembinaan prestasi kelas khusus olahraga. Sehingga sebagai model program pembinaan prestasi tersebut menjadi contoh model program pembinaan yang dapat dijadikan pedoman atau acuan sekolah SMA yang berada di Kota Sukabumi khususnya. Selain itu juga penelitian ini dalam rangka program pembinaan peningkatan prestasi olahraga yang berada di SMA yang nantinya menjadi bahan pertimbangan dan pedoman untuk lebih banyak membuka kelas khusus olahraga di SMA negeri dan swasta lainnya di Kota/Kabupaten Sukabumi.

\section{Evaluasi Program}

Pemahaman tentang pengertian evaluasi program sangat variatif sesuai dengan keahlian bidang dan sudut pandang 
berbagai ilmu pengetahuan. Para ahli mengartikan evaluasi program yang berkaitan dengan kebijakan dalam menentukan tujuan program. Secara umum, istilah evaluasi dapat disamakan dengan penafsiran, pemberian angka, dan penilaian (assessment) kata-kata yang menyatakan usaha untuk menganalisis hasil kebijakan dalam arti satuan nilainya. Suchman dalam Suharsimi Arikunto dan Cepi, memandang evaluasi sebagai sebuah proses menentukan hasil yang telah dicapai beberapa kegiatan yang direncanakan untuk mendukung tercapainya tujuan.

\section{Model Evaluasi Program CIPP}

Model Evaluasi program CIPP merupakan model yang paling banyak dikenal dan diterapkan oleh peneliti atau evaluator baik akademisi maupun institusi pemerintah dan swasta. banyak sekali modelnya yang telah dikembangkan oleh para ahli. Evaluasi program, yang paling populer dan banyak digunakan dalam studi penelitian yaitu model CIPP (Context, Input, Process, and Product) yang diperkenalkan oleh Daniel L. Stufflebeam.

Kriteria Evaluasi

Sebuah program dikatakan berhasil dan sukses apabila memenuhi kriteria keberhasilan yang telah ditetapkan sebelumnya. Membahas mengenai kriteria keberhasilan sebagai patokan evaluasi tidak terlepas dari pembahasan standar, kriteria dan indikator. Makna ketiga konsep tersebut tentunya tidak sama, akan tetapi memiliki kaitan satu dengan lainnya.
Mutrofin dan Hadi menjelaskan kriteria merupakan karakteristik program yang dianggap basis penting untuk melakukan riset evaluasi pada program tersebut (Samsul Hadi, 2006: 77). Hal tersebut sependapat dengan Djaali evaluasi proyek atau program kriterianya adalah tujuan dari pembangunan proyek atau program tersebut, apakah tercapai atau tidak, apakah sesuai dengan rencana atau tidak, jika tidak mengapa terjadi demikian, dan langkah-langkah apa yang perlu ditempuh selanjutnya (Djaali, 2001: 2).

Ada beberapa dasar atau sumber dalam pembuatan kriteria yang disebutkan oleh Arikunto, Abdul Jabar diantaranya (1) peraturan atau ketentuan yang sudah dikeluarkan berkenaan dengan kebijakan yang bersangkutan, (2) buku pedoman atau petunjuk pelaksanaan, (3) konsep atau teori-teori yang terdapat dalam buku-buku ilmiah, (4) hasil penelitian, (5) expert judgement, (6) menentukan kriteria bersama dengan anggota tim atau beberapa orang yang mempunyai wawasan tentang program yang akan dievaluasi, dan (7) melalui pemikiran sendiri (Suharsimi Arikunto, 2001: 32-34).

Bedasarkan urian diatas maka dapat disimpulkan pembuatan kriteria yaitu peraturan sebagai landasan utama dalam menuyusun program yang telah direncanakan, sehingga jelas arah dan tujuan program yang akan dicapai untuk mengambil keputusan. Buku pedoman petunjuk teknis (juknis) dan petunjuk 
pelaksanaan (juklak) merupakan hal yang harus dibuat dalam program agar tidak keluar dari jalur yang sudah ditentukan, pentingnya buku pedoman juklak dan juknis untuk mempermudah memantau pelaksanaan program.

\section{METODE PENELITIAN}

Pelaksanaan penelitian ini menggunakan metode atau pendekatan deskriptif kualitatif, karena tujuannya adalah untuk mendeskripsikan dan menggambarkan apa adanya mengenai suatu variabel, gejala, keadaan atau fenomena sosial tertentu. Dalam hal ini guna menganalisis data yang diperoleh secara mendalam dan menyeluruh, dengan harapan dapat diketahui sejauh mana program pembinaan prestasi kelas khusus olahraga SMA Negeri 1 Kota Sukabumi berjalan dengan baik dan berprestasi.

Desain evaluasi program merupakan suatu rencana yang menunjukan bila evaluasi akan dilakukan, dan dari siapa informasi atau data akan dikumpulkan, desain ini dibuat untuk meyakinkan bahwa evaluasi akan dilakukan menurut organisasi yang teratur dan menurut aturan evaluasi yang baik.

Hasil Penelitian yang Relevan

Beberapa penelitian evaluasi program, yang telah dilakukan, satu diantaranya berjudul " Evaluasi Pembinaan PPLP Balap Sepeda di Jawa Timur" yang dilakukan oleh tim peneliti yaitu Mahmud Yunus, Paryogi Dwina Angga, dan Bustanol Arifin, dalam Jurnal Iptek
Olahraga Volume 12, Nomor 3, edisi September-Desember 2010.

\section{HASIL DAN PEMBAHASAN}

Berdasarkan hal tersebut SMA Negeri 1 Kota Sukabumi telah menyelenggarakan Program Kelas Khusus Olahraga tentunya untuk mencapai tujuan baik akademik maupuan non akademik melalui prestasi olahraga dari tingkat lokal, provinsi, nasional bahkan internasional. Tujuan program pembinaan kelas khusus olahraga SMA Negeri 1 Kota Sukabumi yaitu :

1.Meningkatkan prestasi SMA Negeri 1 Kota Sukabumi dalam bidang olahraga khususnya tingkat Kota Sukabumi, Jawa Barat, Nasional dam Internasional.

2.Meningkatkan kompetensi pendidikan dan peserta didik dalam bidang akademik dan non akademik khususnya bidang olahraga.

3.Memfasilitasi potensi siswa yang ada di Kota Sukabumi yang memiliki kemampuan dan keunggulan khususnya dalam bidang olahraga.

4.Meningkatkan kualitas pendidikan nonakademik khususnya bidang olahraga SMA Negeri 1 Kota Sukabumi untuk menuju prestasi sekolah ke tingkat internasiobal.

Visinya mewujudkan siswa SMA Negeri 1 Kota Sukabumi yang terampil memiliki skill dan prestasi dalam bidang olahraga prestasi tingkat lokal, nasional, maupun internasional. 
Program pembinaan prestasi kelas khsusus olahraga SMA Negeri 1 Kota Sukabumi dikelola oleh guru-guru SMA Negeri 1 Kota Sukabumi yang ditunjuk oleh kepala sekolah. Dalam struktur organisasi sekolah SMA Negeri 1 Kota Sukabumi program pembinaan prestasi kelas khusus olahraga dipegang oleh wakil kepala sekolah bidang pembinaan prestasi olahraga yang bertanggungjawab penuh mengelola dan membina pelaksanaan program kelas khusus olahraga. Ketua program pembinaan prestasi kelas khusus olahraga dibantu oleh 1 orang wakil ketua, 2 orang Sekretaris, 1 orang bendahara, 2 orang bidang akademis, 1 orang bidang sarana, 1 orang bidang disiplin dan 1 orang bidang non-akademi. Cabang olahraga yang dibina SMA Negeri 1 Kota Sukabumi yaitu ; Sepak Bola, Bola Basket, Bola Voli, Futsal, Bulutangkis, Atletik, Pencak Silat, Renang, Taekwondo, Anggar, Karate, dan cabang olahraga lainnya.

Program pembinaan prestasi kelas khusus menampung sebanyak 120 atlet/siswa yang terbagi menjadi 3 kelas, setiap kelas maksimal 40 siswa. Setiap kelas atlet/siswa tidak hanya satu atau dua cabang olahraga, akan tetapi dicampur pada masing-masing kelas. Sehingga pada saat mengikuti kejuaraan setiap kelas masih ada siswa yang lain mengikuti kegiatan belajar. Begitu pula dengan jadwal latihan, dilaksanakan pada sore hari setelah selesai mengikuti kegiatan belajar. Dalam satu minggu biasanya setiap cabang olahraga melakukan sesi latihan 3 kali dalam satu minggu, hari latihannya disesuaikan dengan para pelatih. Pelaksanaan latihan ada yang menggunakan latihan di dalam sekolah SMA Negeri 1 Kota Sukabumi dan diluar sekolah bekerjasama dengan club atau pengurus cabang olahraga yang memiliki fasilitas/sarana dan prasarana yang bisa disewakan. Cabang olahraga yang latihannya di sekolah yaitu bola basket, bola voli, Karate, futsal dan pencak silat.

Sistem pengrekrutan siswa calon atlet kelas khusus olahraga melalui beberapa tahap seleksi, sesuai dengan Surat Keputusan Walikota Sukabumi yang tertuang dalam petunjuk teknis penerimaan peserta didik baru (PPDB) secara eksplisit dijelaskan. Khusus kelas atlet, tahapannya memakai point/nilai hasil ujian, sertifikat mengikuti kejuaraan dan tes skill (kemampuan) masing-masing cabang olahraga yang diikuti sehingga bisa dibuktikan bahwa siswa tersebut seorang atlet. Dalam pelaksanaan seleksi penilaian dengan sertifikat dan tes kemampuan, SMA Negeri 1 Kota Sukabumi melibatkan pengurus KONI Kota Sukabumi dan Pengurus Cabang Olahraga (Pengcab) tingkat kota/kabupaten. Sehingga atlet yang diseleksi benar-benar yang berprestasi dan kemampuannya sudah terbukti.

Begitupula dengan pengrekrutan pelatih, SMA Negeri 1 Kota Sukabumi melibatkan pengcab untuk memilih pelatih 
yang bersertifikat/lisensi kepelatihan pelatih dan berpengalaman dalam melatih tim/club. Terbukti dengan prestasi yang diraih SMA Negeri 1 Kota Sukabumi selalu menjuarai kompetisi atau kejuaraan baik tingkat regional, kota/kabupaten, provinsi, nasional dan internasional.

Sarana dan prasarana yang dimiliki SMA Negeri 1 Kota Sukabumi terbatas dengan beberapa faktor yaitu luas sekolah \pm 6000 meter persegi hanya tersedia lapangan bola basket, lapangan bola voli dan lapangan futsal yang secara bergantian lapangan tersebut digunakan untuk latihan. Sehingga pihak sekolah bekerjasama dengan pengcab dan club olahraga untuk dapat memfasilitasi siswa atlet untuk berlatih walaupun dengan cara menyewa dengan diberikan keringanan membayar.

Dana operasional untuk pelaksanaan program pembinaan prestasi kelas khusus didapat dari sumbangan orangtua yang membayar saat anaknya diterima masuk kelas khusus olahraga yang disebut sumbangan awal tahun (SAT). selain itu dana yang didapat dari Bantuan Operasional Sekolah (BOS) Pusat dari Kementerian Pendidikan dan Kebudayaan, BOS Provinsi Jawa Barat dan BOS Dinas Pendidikan Kota Sukabumi. Adapaun pihak pemerintah daerah dan swasta sampai saat ini belum ada yang memberikan donasi dalam bentuk uang untuk pelaksanaan operasional kelas khusus olahraga.

\section{SIMPULAN}

Program pembinaan prestasi olaharaga merupakan salah satu program yang direncanakan untuk mencapai prestasi yang ingin dicapai. Sekolah Menengah Atas (SMA) Negeri 1 Kota Sukabumi merupakan sekolah yang menampung atlet pelajar yang berprestasi dalam bentuk model pembinaan prestasi kelas khusus olahraga. Sehingga pelaksanaan pembinaan prestasi baik secara akademik dan non akademik yaitu olahraga menjadi prioritas utama pendidikan bisa dilaksanakan secara seimbang.

Tujuan program pembinaan prestasi kelas khusus olahraga SMA Negeri 1 Kota Sukabumi secara kontinyu dan berkesinambungan untuk membina atlet yang berbakat dan berprestasi dalam upaya mencapai prestasi puncak dan tercapai pendidikan secara umum. Selain itu mendukung program pemerintah daerah dalam hal peningkatan prestasi olahraga yang dimiliki Kota Sukabumi sebagai aset daerah untuk bisa berpretasi mengharumkan nama Kota Sukabumi di kanca olahraga baik tingkat regional, provinisi, nasional dan internasional.

Hambatan yang menjadi salah satu tersendatnya pelaksnaan program pembinaan prestasi kelas khusus olahraga yaitu keterbatasan fasilitas baik sarana dan prasarana di sekolah untuk menunjang kegiatan latihan bagi sleuruh atlet binaan kelas khusus olahraga SMA Negeri 1 Kota Sukabumi, menjadi perhatian serius seluruh pihak baik pemerintah daerah, 
dinas terkait, dan stakeholder olahraga untuk mendukung lancarnya kegiatan pelaksanaan program latihan dan mengikuti kompetisi atau kejuaraan.

Hal yang paling penting adalah dukungan dana atau anggaran program pembinaan prestasi kelas khusus olahraga yang masih minim, karena masih mengandalkan bantuan dana operasional sekolah dan sumbangan dari orangtua siswa yang masuk dalam kelas khusus olahraga. Maka perlu dukungan dari pihak pemerintah daerah dan swasta untuk bisa membantu dalam hal pendanaan dalam pelaksanaan program latihan dan kompetisi/kejuaraan. Dengan adanya evaluasi program yang dilaksanakan diharapkan dapat mengurangi setiap faktor kendala yang ada pada pelaksanaan program pembinaan prestasi kelas khusus olahraga dan dapat diminimalisir secara bertahap akan dapat diselesaikan masalah dan kendala tersebut.

\section{DAFTAR PUSTAKA}

Adi, R., \& Muhamad, S. T. (2020). Technology Innovation and Learning Media in Industrial Revolution Era 4 . O ( Blended Learning ) in Physical Education. 120-122.

Daniel L. Stufflebeam, Evaluation: Theory, Model, Application, San Francisco: CA Whiley, 2007.

Djaali dan Pudji Mujiono, Pengukuran dalam Bidang Pendidikan, Jakarta: Grassindo, 2001.

Guntur Gaos, M., Taufik, M. S. (2019). Meningkatkan Teknik Dasar Dribbling Sepakbola Melalui
Modifikasi Permainan. Maenpo, 8(1), 14.

Peraturan Pemerintah Republik Indonesia Nomor 16 Tahun 2007, tentang

Penyelenggaraan Keolahraga,

Jakarta: Kementerian Pemuda dan

Olahraga, 2011.

Rusli Lutan, Pedoman Perencanaan Pembinaan Olahraga, Bandung: PT. Remaja Rosdakarya, 2013.

Samsul Hadi dan Mutrofin, Pengantar Metode Riset Evaluasi, Yogyakarta: Kurnia Kalam Semesta, 2006.

Sugiyono, Memahami Penelitian Kualitatif, Bandung: CV. Alfabeta, 2005.

Suharsimi Arikunto, Prosedur Penelitian Suatu Pendekatan Praktik, Jakarta: Rieneka Cipta, 2010.

Dasar-Dasar Evaluasi Pendidikan, Jakarta: Bumi Aksara, 2010.

Suharsimi Arikunto dan Cepi Safrudin Abdul Jabar, Evaluasi Program Pendidikan, Jakarta: Bumi Aksara, 2001. https://doi.org/10.35194/jm.v8i2.925

Taufik, M. S. (2018). Meningkatkan Teknik Dasar Dribbling Sepakbola Melalui Modifikasi Permainan. MAENPO, 8(1), 26. 